\title{
Methanotrophic activity and microbial community dynamics in a UASB sludge
}

This study determined the methanotrophic activity in anaerobic sludge from a pilot-scale UASB reactor. Four batch experiments, with three replicates, were performed in $110 \mathrm{~mL}$ antibiotic flasks. The results showed that the maximum rate was $115 \mu \mathrm{molCH}_{4} \cdot \mathrm{d}^{-1}$ and the methanotrophic activity was $2.3 \mathrm{mmolCH} \mathrm{m}_{4} . \mathrm{gTVS}$ ${ }^{1} . \mathrm{d}^{-1}$, indicating that the methanotrophic microorganisms play a key role within the UASB reactor since they are part of the sludge microbiota and may consume some of the methane produced inside the reactor. Therefore, these microorganisms may reduce possible methane losses, either atmospheric and/or dissolved in the treated effluent. The microbial community was investigated by molecular tools (PCR-DGGE) and two DNA sequences related to methanotrophic bacteria, Methylocystis sp. (similarity of 93\%) and Methylocaldum sp. (similarity of 98\%) to $16 \mathrm{~S}$ rRNA gene sequences, were detected. The methanotrophic activity and the identification of the community of main microorganisms involved allow the reduction of methane into the atmosphere and contribute to the system's mass balance between production and consumption.

Keywords: Anaerobic Gas; Chromatograph; Methane Oxidation; Pilot-Scale; Sludge.

\section{Atividade metanotrófica e dinâmica da comunidade microbiana em lodo de UASB}

Para determinação da atividade metanotrófica em lodo anaeróbio de um reator UASB operando em escala piloto, foram montados quatro experimentos em triplicata utilizando frascos de antibióticos de $110 \mathrm{~mL}$. Os resultados mostraram que a taxa máxima produzida foi de $115 \mu \mathrm{mol} \mathrm{CH}_{4} \cdot \mathrm{d}^{-1} \mathrm{e}$ a atividade metanotrófica $2,3 \mathrm{mmolCH}_{4} \cdot \mathrm{gTVS}^{-1} \cdot \mathrm{d}^{-1}$, indicando que os microrganismos metanotróficos desempenham um papel fundamental dentro do reator UASB, uma vez que fazem parte da microbiota do lodo e podem consumir parte do metano produzido dentro do reator. Portanto, esses microrganismos podem reduzir possíveis perdas de metano seja atmosférico e/ou dissolvido no efluente tratado. A comunidade microbiana foi investigada com auxílio de ferramentas de biologia molecular (PCR-DGGE) e duas sequências de DNA relacionadas a bactérias metanotróficas, Methylocystis sp. (similaridade de 93\%) e Methylocaldum sp. (similaridade de $98 \%$ ) para sequências do gene 16S rRNA, foram detectados. A atividade metanotrófica e a contribuição predominante da comunidade de microrganismos envolvidos permitem a redução do metano na atmosfera e contribuem para o balanço de massa do sistema entre produção e consumo.

Palavras-chave: Gás Anaeróbio; Cromatógrafo; Oxidação de Metano; Escala Piloto; Lodo.

Topic: Engenharia Sanitária

Reviewed anonymously in the process of blind peer
Received: 03/01/2021

Approved: 25/01/2021
Luciene Alves Batista Siniscalchi (iD)

Universidade Federal de Lavras, Brasil

http://lattes.cnpq.br/7511499030309427

http://orcid.org/0000-0001-7892-0112

luciene.batista@ufla.br

Juliano Curi de Siqueira (iD

Universidade Federal de Lavras, Brasil

http://lattes.cnpq.br/3988696956508686

http://orcid.org/0000-0002-6346-8917

julianocuri2015@gmail.com

Paula Peixoto Assemany

Universidade Federal de Lavras, Brasil

http://lattes.cnpq.br/1498629994153004

http://orcid.org/0000-0001-7596-7804

paula.assemany@ufla.br

\author{
Ana Maria Moreira Batista (iD \\ Universidade do Estado de Minas Gerais, Brasi \\ http://lattes.cnpq.br/9828460785699072 \\ http://orcid.org/0000-0002-9836-267X \\ ana.batista@uemg.br \\ Giuliano Siniscalchi Martins (iD) \\ Instituto Federal de Minas Gerais, Brasil \\ http://lattes.cnpq.br/8886004663129168 \\ http://orcid.org/0000-0002-8258-8527 \\ giuliano.martins@ifmg.edu.br \\ Juliana Calabria de Araújo \\ Universidade Federal de Minas Gerais, Brasil \\ http://lattes.cnpq.br/3412076785602816 \\ http://orcid.org/0000-0002-5497-8675 \\ juliana@desa.ufmg.br
}

Referencing this:

SINISCALCHI, L. A. B.; SIQUEIRA, J. C.; ASSEMANY, P. P.; BATISTA, A. M. M.; MARTINS, G. S.; ARAÚJO, J. C.. Methanotrophic activity and microbial community dynamics in a UASB sludge. Revista lbero Americana de Ciências Ambientais, v.12, n.1, p.312-321, 2021. DOI: http://doi.org/10.6008/CBPC2179-6858.2021.001.0026 


\section{INTRODUCTION}

Methane is formed through the methanogenesis process which is the organic matter fermentation final step. This process occurs in a variety of anoxic environments, e.g., rice fields, animals' intestines, soils, sediments, freshwater sediments, landfills, and in wastewater treatment plant (WWTP) processes such as anaerobic systems treating domestic sewage or industrial wastewater (KALYUZHNAYA et al., 2015). About $60 \%$ of the global $\mathrm{CH}_{4}$ budget came from these processes and environments resulting in a methane global rate estimated at 500 to $600 \mathrm{TgCH}_{4} \cdot \mathrm{yr}^{-1}$ (CONRAD, 2009).

In anaerobic systems, such as upflow anaerobic sludge blanket (UASB) reactors, methane is produced within the system to form the biogas, which is captured by the three-phase separator (CHERNICHARO et al., 2015). However, it may also be detached from the final effluent as dissolved methane, which contributes to the greenhouse effect, representing environmental and economic losses (CAKIR et al., 2005; LOBATO et al., 2012).

It is known that methane oxidizer microorganisms are present in these systems. Methanotrophic groups use methane and other C1 compounds as a source of carbon and energy (MATSUURA et al., 2017). Aerobic oxidation is performed by bacteria that use methane monooxygenase (MMO) enzymes to oxidize methane to methanol (LUESKEN et al., 2011). Anaerobic oxidation may be performed by nitrite-dependent anaerobic methane oxidation (N-DAMO) bacteria and anaerobic methanotrophic archaea (ANME) (KAMPMAN et al., 2018).

Studies have investigated methane oxidation in WWTPs. Meulepas et al. (2010) obtained an oxidation rate of $11.4 \mu \mathrm{molCH}_{4} . \mathrm{gVSS}^{-1} \cdot \mathrm{d}^{-1}$ evaluating methane oxidation of UASB sludge treating industrial wastewater, and also evaluated the role of methane oxidation in activated sludge system, sludge digesters, and an oxygen-limited autotrophic biological system (nitrification/denitrification) used to treat high nitrogen concentration wastewater. The highest oxidation potential could be verified in the activated sludge which presented an oxidation rate of $160.32 \mathrm{mmolCH}_{4} \cdot \mathrm{gVSS}^{-1} . \mathrm{d}^{-1}$ (HO et al., 2014). In this sense, new possibilities for the dissolved methane removal in anaerobic effluent would be a post-treatment by microorganisms, which could biologically oxidize methane (KALYUZHNAYA et al., 2015). According to Brandt et al. (2018), it is possible to design biofilters for the removal of residual methane released from effluents. In this case, it is recommended to install two biofilters arranged in series: the first one will treat odorous gases, and the second one directed to treat $\mathrm{CH}_{4}$, since the acidic conditions found in biofilters may affect the methanotrophic activity.

In the Brazilian context, basic sanitation needs investments in the overall sectors (e.g., water supply, solid waste management, and mainly in sewerage). About $45.9 \%$ of Brazilians still do not have access to sewage collection networks (SNIS, 2020). Optimizing sewage treatment technologies may greatly contribute to reducing this inequality, because like most developing countries, Brazil is limited to the secondary treatment level by aerobic or anaerobic processes (VON SPERLING, 2014). Furthermore, methane production in treatment systems would be relevant from environmental and socio-economic aspects with great 
relevance in developing countries.

Therefore, we aimed to determine the maximum methane consumption performed by anaerobic batch tests from a UASB reactor sludge, as well as to determine the predominant microbial community selected over time using biological molecular tools (PCR-DGGE).

\section{MATERIALS AND METHODS}

\section{Anaerobic methane oxidation test}

The experiment was performed to evaluate anaerobic methanotrophic activity in UASB sludge samples. Four batch experiments (tests 1, 2, 3, and 4), with three replicates each, were performed in $110 \mathrm{~mL}$ antibiotic flasks. Before sludge sampling, the concentration of total volatile solids (TVS) was measured according to APHA (2005) in order to determine the volume of sludge to be added to $110 \mathrm{~mL}$ flasks, to obtain 5 gTVS.L $^{-1}$ (CHERNICHARO, 2017). After adding the inoculum, the sludge was supplemented with $20 \mathrm{~mL}$ of culture medium previously sterilized according to Luesken et al. (2011). The flasks were sealed with rubber bungs (butyl) and aluminum seals and the atmosphere was "washed" with inert gas $\left(\mathrm{N}_{2}-99.9 \%\right)$ to anaerobiosis and incubated at $30{ }^{\circ} \mathrm{C}$ in an orbital shaker at $250 \mathrm{rpm} .20 \mathrm{~mL}$ of $\mathrm{CH}_{4}$ was added utilizing a glass ground syringe. Autoclaved sludge flasks were incubated as control.

\section{Gas analysis}

Subsequently, $1 \mathrm{~mL}$ of headspace gas sample was taken twice a week to check methane decay. Gas was measured using a gas chromatograph (GC) (Perkin Elmer Auto System) equipped with a thermal conductivity detector (TCD). Chromatographic analyses occurred using He gas as a carrier gas and column temperature at $220^{\circ} \mathrm{C}$. Each run had a total duration of $4.5 \mathrm{~min}$, and the methane retention time occurred around $2.75 \mathrm{~min}$. Standard curves for the calculation of the gas concentrations were established using standard gas $\left(47.1 \% \mathrm{CH}_{4}, 25 \% \mathrm{CO}_{2}, 2 \% \mathrm{H}_{2}, 5 \% \mathrm{CO}\right.$, and $\left.20.9 \% \mathrm{~N}_{2}\right)$ and area of known peaks.

After 34 days, accumulated methane consumption data was processed in programming language $\mathrm{R}$ 3.6.3 (R Development Core Team) for methane consumption determination. For each test, linear and sigmoidal models (Logistic and Gompertz) were adjusted. For the model comparison, it was considered the coefficient of determination $\left(R^{2}\right)$, the residual sum of squares (RSS), and the significance level of the coefficients ( $p$-value).

Methane consumption rate $\left(\mathrm{mLCH}_{4} \cdot \mathrm{d}^{-1}\right)$ was obtained by dividing the maximum consumption value $\left(\mathrm{mLCH}_{4}\right)$ by the load of total volatile solids (gTVS) of the sludge added to each flask.

\section{DNA extraction and PCR-DGGE}

Inoculated sludge samples, as well as the enriched biomass at the assay end (after 34 days of incubation), were collected for molecular analysis of Test 3. DNA was extracted according to Egli et al. (2003) and amplified by polymerase chain reaction (PCR). For this purpose, $30 \mathrm{ng} \cdot \mu \mathrm{L}^{-1}$ of DNA was added to $50 \mu \mathrm{L}$ of 
reaction. The primers used were 1055F (5'ATGGCTGTCGTCAGCT 3') and 1392R-GC (5'ACGGGCGTGTAC 3'), for the RNAr 16S V8 region of the Bacteria domain. To confirm the amplicons presence, $2 \mu \mathrm{L}$ of each one was submitted to $1 \%$ agarose gel electrophoresis with GelRed solution (Biotium ${ }^{\circledR}$ ), 10x buffer (Phoneutria ${ }^{\circledR}$ ), and Low Mass DNA Ladder (Invitrogen ${ }^{\circledR}$ ), as the reference standard for DNA quantification. The software ImageJ (Image Processing and Analysis in Java ${ }^{1}$ ) was used for gel photograph analysis and estimating the DNA present amount.

The amplicons containing $400 \mathrm{ng}$ of DNA from the inoculum samples and oxidation test end were submitted to electrophoresis run at $60{ }^{\circ} \mathrm{C}$ in TAE (Tris-Acetate-EDTA) buffer 0.5 for $17 \mathrm{~h}$ at $80 \mathrm{~V}$ in a Bio-Rad DCode Universal Mutation Detection System (Hercules, CA, USA), using an 8\% polyacrylamide gel and a denaturing gradient of 45 to $75 \%$. The gels colored with Sybr-Gold (Life Technologies) solution for 30 minutes were visualized under ultraviolet light and the bands contained excised from the gels and eluted in $50 \mu \mathrm{L}$ of TE (Tris-EDTA) buffer remaining $4{ }^{\circ} \mathrm{C}$ for $48 \mathrm{~h}$.

\section{Analysis of DGGE band sequences}

Eluted DNA was re-amplified with primers 1055-1392 (without the GC clamp). The purified PCR products were sent for unidirectional sequencing (primer 1055F) at Macrogen Inc (South Korea) by a 3730XL sequencer. From the direct sequence obtained (forward), the reverse sequence (reverse complement) was also obtained through the software Sequence Manipulation Suite ${ }^{2}$ (STOTHARD, 2000). The direct and reserve sequences (forward-reverse) were aligned through the software FASTA ${ }^{3}$ (University of Virginia).

Aligned sequences were used for comparison by the Ribosomal Database Project databases through the software RDP Classifier ${ }^{4}$ and the NCBI (National Center of Biotechnology Information ${ }^{5}$ ) through the BLAST (Basic Local Alignment Search Tool).

\section{RESULTS AND DISCUSSION}

\section{Methanotrophic activity}

Data were adjusted for the Logistic, Gompertz, and Linear models and showed the optimum $\mathrm{R}^{2}$ (Test $1=0.96$; Test $2=0.99 ;$ Test $3=0.98$; Test $4=0.99$ ), RSS, and $p$-value of coefficients ( 0 and 0.001 ) for Gompertz Model. Figure 1 presents the models adjustment for the tests.

It was verified that the UASB sludge methanotrophic activity should be taken into account, as it is part of the reactor methane balance. The maximum methane rate was $115.5 \mu \mathrm{molCH} \cdot \mathrm{d}^{-1}$ and the maximum methanotrophic activity average was $2.33 \mathrm{mmolCH}_{4} \cdot \mathrm{gTVS}^{-1} \cdot \mathrm{d}^{-1}$. Table 1 presents maximum specific methanotrophic activity values obtained for each test (1 to 4 ) and average values.

\footnotetext{
${ }^{1}$ http://imagej.nih.gov/ij/

${ }^{2}$ http://www.bioinformatics.org/sms2/rev comp.htm

${ }^{3}$ http://fasta.bioch.virginia.edu/fasta www2/fasta www.cgi?rm=select\&pgm=fad

4 https://rdp.cme.msu.edu/classifier/classifier.jsp

5 http://www.ncbi.nlm.nih.gov/
} 
Table 1: Maximum methanotrophic activity consumption rate and methanotrophic activity of UASB sludge samples.

\begin{tabular}{ccccc}
\hline Sample & $\begin{array}{c}\mathrm{CH}_{4} \text { maximum rate } \\
\left(\mathrm{mLCH}_{4} \cdot \mathrm{d}^{-1}\right)\end{array}$ & $\begin{array}{c}\mathrm{CH}_{4} \text { maximum rate } \\
\left(\mu \mathrm{molCH}_{4} \cdot \mathrm{d}^{-1}\right)\end{array}$ & $\begin{array}{c}\text { Methanotrophic activity } \\
\left(\mathrm{mLCH}_{4} \cdot \mathrm{gTVS}^{-1}\right)\end{array}$ & $\begin{array}{c}\text { Methanotrophic activity } \\
\left(\mathrm{mmolCH}_{4} \cdot \mathrm{gTVS}^{-1} . \mathrm{d}^{-1}\right)\end{array}$ \\
\hline Test 1 & 1.6 & 65 & 33.8 & 1.4 \\
Test 2 & 2.9 & 119 & 89.1 & 3.6 \\
Test 3 & 2.7 & 112 & 35.0 & 1.4 \\
Test 4 & 4.0 & 164 & 68.9 & 2.8 \\
Average & $\mathbf{2 . 8}$ & $\mathbf{1 1 5 . 5}$ & $\mathbf{5 6 . 7}$ & $\mathbf{2 . 3 3}$ \\
\hline
\end{tabular}
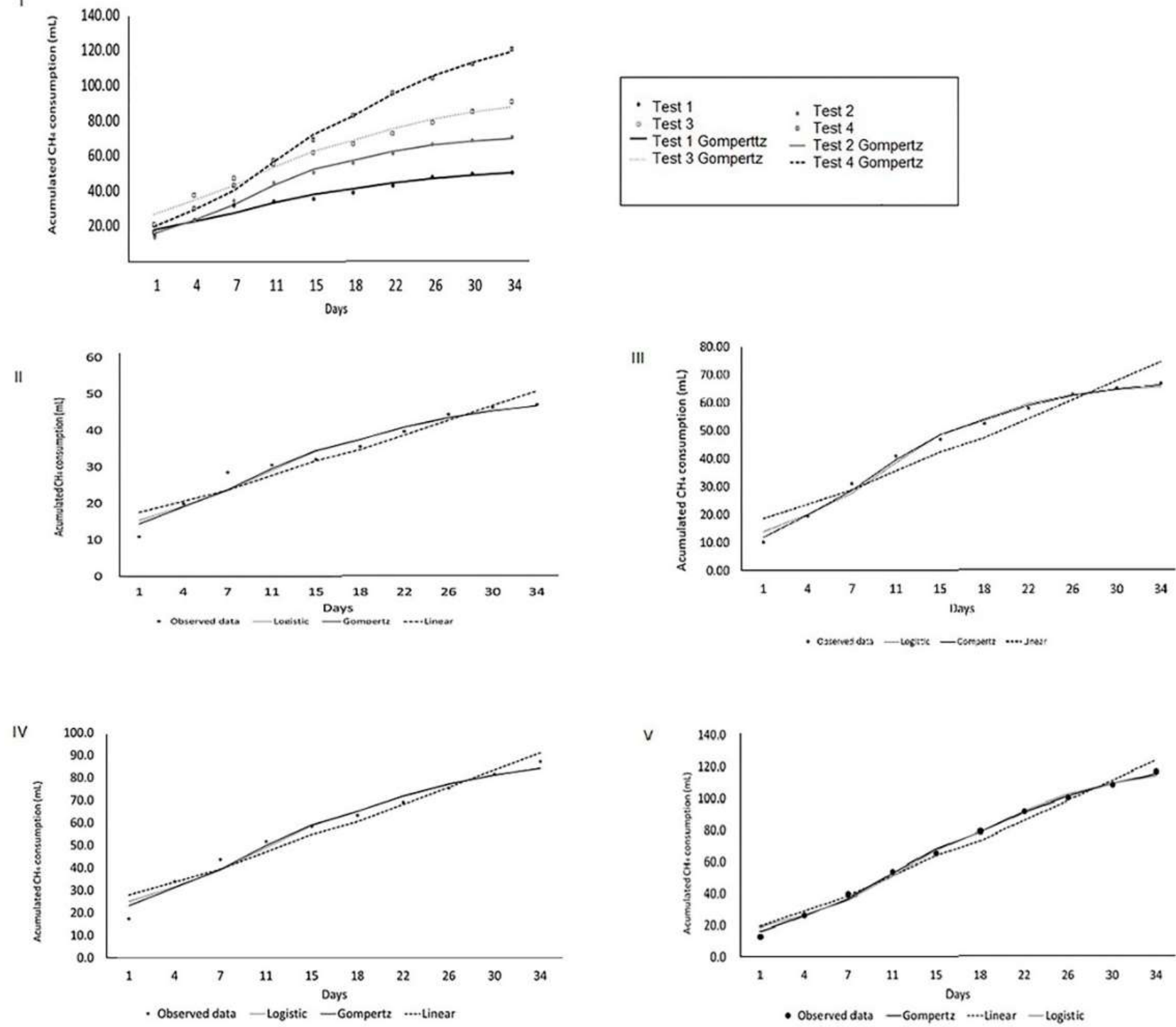

Figure 1: Accumulated $\mathrm{CH}_{4}$ consumption scatter plot. I. All tests (1 to 4 ) and Gompertz adjust. II to V. Tests containing the curve adjusted to the data by the Logistic, Gompertz, and Linear models. II: Test 1. III: Test 2. IV: Test 3. V: Test 4.

Results were superior to those found by Knief et al. (2003), who estimated methane oxidation maximum rates ranging from 0.01 to $3.11 \mathrm{nmolCH}_{4} \cdot \mathrm{g}^{-1} \cdot \mathrm{h}^{-1}$. However, the study used samples of the soil superficial horizon ( 5 to $20 \mathrm{~cm}$ ) from Germany, Italy, and Holland, and they were incubated at $25{ }^{\circ} \mathrm{C}$ temperature below the present study. Some authors (ETTWIG et al., 2009) present a methane consumption activity rate of approximately $0.18 \mathrm{nmolCH}_{4} \cdot \mathrm{min}^{-1}$ per $\mathrm{mg}$ of protein with a culture enriched from sediments of agricultural ditches and freshwater in batch experiments using a culture enriched with methanotrophic microorganisms.

Moreover, methane uptake was carried out in $100 \mathrm{~mL}$ batch reactors incubated in a shaker (40 rpm) 
at $30^{\circ} \mathrm{C}$ by methanotrophs in methanotrophic denitrificant reactors (RDM) (CUBA et al., 2001). The RDM was fed with nitrate and nitrite 0.009 and 0.005 mol. $\mathrm{L}^{-1}$, respectively, corresponding to uptake rates of 0.52

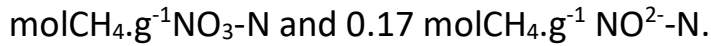

After analyzed samples of Canadian Arctic soil (permafrost) incubated in a medium containing mineral salts or added directly to glass flasks, the researchers (MARTINEAU et al., 2010) detected

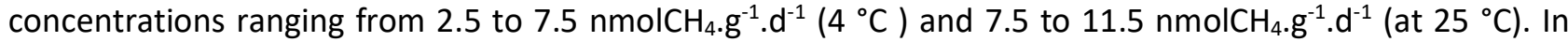
contrast, when the mineral medium was added, the oxidation rates at $4{ }^{\circ} \mathrm{C}$ were approximately 100 $\mathrm{nmolCH} 4 \cdot \mathrm{g}^{-1} \cdot \mathrm{d}^{-1}$, whereas the rates for oxidation at $25{ }^{\circ} \mathrm{C}$ ranged from $300 \mathrm{nmol}$ to $550 \mathrm{nmolCH}_{4} \cdot \mathrm{g}^{-1} \cdot \mathrm{d}^{-1}$. The nutrient deficiency may be an important factor that limits the activity of methanotrophic bacteria in Arctic soils (MARTINEAU et al., 2010) and explains low oxidation values.

Some authors investigated the labeled methane (13C) oxidation in samples of granular sludge obtained from three UASB reactors in full scale. The composite sample was incubated and the oxidation rate presented was $11.4 \mu_{\mathrm{molCH}} \cdot \mathrm{gVSS}^{-1} \mathrm{~d}^{-1}$ (MEULEPAS et al., 2010). In a study by Ho et al. (2013), the methane oxidation potential from sludge samples from different WWTPs was $160.32( \pm 17.79) \mathrm{mmolCH}_{4} . \mathrm{gVSS}^{-1}$ for anoxic sludge from the activated sludge system (AS) and $34.66( \pm 0.94) \mathrm{mmolCH}_{4} . \mathrm{gVSS}^{-1}$ for the AS return sludge. For sludge from anaerobic digesters, the total methane consumed was $22.09( \pm 1.02) \mathrm{mmolCH}_{4 . \mathrm{gVSS}}$ 1; and finally, for the laboratory-scale OLAND system, the result was $85.16( \pm 2.69) \mathrm{mmolCH}_{4} . \mathrm{gVSS}^{-1}$ and 35.19 $( \pm 5.71) \mathrm{mmolCH}_{4} \cdot \mathrm{gVSS}^{-1}$ for industrial-scale OLAND.

It was observed that values achieved in the present study were lower than those found for anaerobic digesters treating waste and AS (MEULEPAS et al., 2010; HO et al., 2013), however, higher than rates of UASB granular sludge oxidation treating industrial effluent. It is worth noting that different methodologies promote tests with different temperatures, pressure (BHATTARAI et al., 2018), compositional change of culture media (MARTINEAU et al., 2010), low concentrations of dissolved oxygen (KAMPMAN et al., 2018), and inoculum (SINISCALCHI et al., 2017). These experiments stimulate different biotic interactions which occur over time and can potentially alter the methane oxidation activity (HO et al., 2013).

Furthermore, this research aimed to determine the maximum accumulated production over the test period in order to demonstrate how important it would be to consider the presence of methanotrophic in the treatment systems. When considering smaller scale reactors, methane oxidation is interesting from an environmental and economic point of view (GÜR et al., 2016). However, it is worth mentioning that in the large-scale case, dissolved methane would represent energy loss, since methane could be used to generate electricity at the treatment plant itself or for local use and/or with the concessionaire (LOBATO et al., 2012). In anaerobic reactors, the methane composition in the biogas is estimated to be $60-85 \%$. The methane calorific value is $35.9 \mathrm{MJ} . \mathrm{Nm}^{-3}$ and for biogas with $60 \%$ methane is $21.5 \mathrm{MJ}^{-\mathrm{Nm}^{-3}}$, corresponding to $67 \%$ of the natural gas calorific value (LOBATO et al., 2012; ROSA et al., 2015). The electricity generation through biogas from anaerobic sewage treatment systems in Brazil indicates economic viability for cities with a population of over 300,000 inhabitants (SANTOS et al., 2016).

In Minas Gerais, state of the present study, Campello et al. (2020) evaluated the economic viability 
of exploiting for electric power generation, biogas generated by anaerobic digestion of sewage and sewage sludge in treatment plants. They demonstrated potential for electricity generation of about 47,140 MWh per year and a potential reduction in emissions of greenhouse gas (GHG) close to $325,800 \mathrm{tCO}_{2}$ eq.yr $\mathrm{r}^{-1}$.

The impact of dissolved methane from sewage treatment systems on the greenhouse effect could be as high as the impact of emissions from recovered methane on biogas, especially in the case of low chemical oxygen demand (COD) influent concentrations, in which there are no economic possibilities to implement energy recovery from biogas (CAKIR et al., 2005). In this sense, the possibility of using biological oxidation is a way to minimize the environmental impacts of these systems.

\section{Microbiological community dynamics}

A large number of bands was obtained and kept from the two samples analyzed, however only the sequences of the bands listed on the gel (Figure 2) were recovered, and this amount proved to be enough to assess the diversity of the samples (Table 2). Channel 1 corresponded to the test of the inoculum sample (UASB sludge), while channel 2 contained the biomass after 34 days of the test start-up. Most bands showed high similarity with non-cultivated bacteria clones from environmental samples.
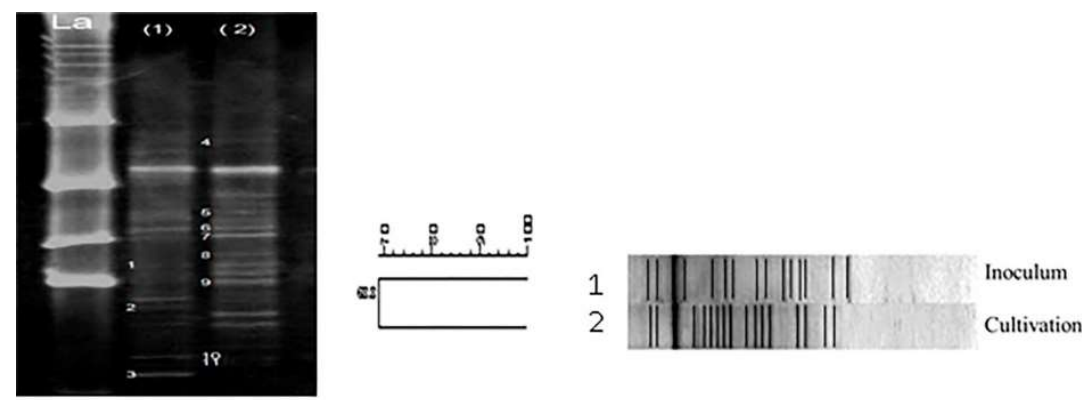

Figure 2: DGGE gel colored with SYBR and Dendrogram generated based on band profile. Gold containing a $16 \mathrm{~S}$ ribosomal DNA fragment amplified with universal Bacteria primers (La) molecular weight marker (Ladder Express); (1) UASB sludge used as inoculum for the anaerobic methane oxidation test; (2) sludge sample at the end of the anaerobic methane oxidation test ( 34 days of incubation).

Table 2: Alignments of the sequences obtained from the bands with the software RDP Classifier and Blast.

\begin{tabular}{cl|lcc}
\hline Band number & \multicolumn{1}{c|}{ RDP Classifier } & \multicolumn{1}{c}{ Blast } & GenBank Access Number & Similarity (\%) \\
\hline 1 & Class Alphaproteobacteria & Methylocystis sp. & EU647258.1 & 93 \\
2 & Domain Bacteria & Uncultivated Mycobacterium sp. clone & EU631845.1 & 87 \\
3 & Family Synergistaceae & Uncultivated Synergistetes & AB908684.1 & 98 \\
4 & Domain Bacteria & Uncultivated Acidobacteriaceae & KP717505.1 & 98 \\
5 & Domain Bacteria & Uncultivated Desulfuromonadaceae & KC009900.1 & 77 \\
6 & Domain Bacteria & Acidovorax sp. & KP126996.1 & 86 \\
7 & Genus Methylocaldum & Uncultivated Methylocaldum sp & HF565149.1 & 98 \\
8 & Domain Bacteria & Uncultivated Planctomycetales clone & FJ710625.1 & 95 \\
9 & Genus Solirubrobacter & Uncultivated Solirubrobacter sp. & HQ213036.1 & 99 \\
10 & Phylum Chloroflexi & Uncultivated Chloroflexi & AY921707.1 & 98 \\
11 & Domain Bacteria & Uncultivated Armatimonadetes & KJ600041.1 & 95 \\
\hline
\end{tabular}

Methanotrophic microorganisms were observed in bands 1 and 7. Band 1 showed $93 \%$ similarity with the genus Methylocystis sp. (class Alphaproteobacteria), and band 7 showed 98\% similarity with the sequence of Methylocaldum sp. (class Gammaproteobacteria).

One of these sequences (band 1) showed high similarity with the Methylocystis genus. 
Methanotrophs of the genus Methylocystis sp. are generally in the rod-shape and simple arrangements (BRENNER et al., 2005). They have been reported in environments such as rice fields, sewers, and freshwater sediments (BRENNER et al., 2005). The community of the acidic peatlands of southern Brazil was investigated and found methanotrophs related to Methylocystaceae and Methylococcaceae (ETTO et al., 2012), as well as in the Amazon region where detected the same families (Methylocystaceae and Methylococcaceae) (FINN et al., 2020; TESSARO, 2012).

Bands 2 and 6 were classified at the domain level by the RDP Classifier, showing 87 and $86 \%$ of the similarity with the genera Mycobacterium and Acidovorax, respectively. The genus Mycobacterium (phylum Actinobacteria) is composed of numerous pathogenic bacteria and species whit bioremediation ability (DAS et al., 2015).

Acidovorax has also been described in domestic sewage sludge samples and soils, including contaminated soils with polycyclic aromatic hydrocarbons (SINGLETON et al., 2009). Band 9 was classified at genre level with 99\% similarity with Solirubrobacter (phylum Actinobacteria). Members of this genus are chemorganotrophic, growing at a temperature of 19 to $38^{\circ} \mathrm{C}$, and have already been isolated from soils containing crops (SINGLETON et al., 2009).

Bands 3, 10, and 11 were classified at the phylum level, with band 3 showing identity with Synergistetes, band 10 with the phylum Chloroflexi, and band 11 with the phylum Armatimonadetes (previously classified as OP10). The three phyla are composed of microorganisms that contain anaerobic representatives and have also been mentioned as present in sewage treatment systems (GANESAN et al., 2012).

Bands 4 and 8 were identified as Acidobacteriaceae and Planctomycetales, respectively. The Acidobacteriaceae family is composed of chemorganotrophic microorganisms, found in soils, sediments, wastewater, water distribution systems, acid mine drainage, hydrothermal vents, among others (ZEKKER et al., 2015).

The DGGE band profile was compared using the software BioNumerics (version 7.1), which indicated the similarity coefficient between the initial sample (inoculum) and after 34 days of incubation (anaerobic methane oxidation test) by analyzing the presence/absence of similar bands (Figure 2).

By using the Dice coefficient, it was observed $69 \%$ of similarity among the samples, indicating that there was a change in the microbial community inside the flasks, under the test conditions, such as the methane and culture medium addition. Therefore, the sample incubation for 34 days led to a methanotrophic selection and enrichment related to the genus Methylocaldum (i.e., aerobic methanotrophs), but have also been reported in anoxic environments, such as in UASB reactor and fermenter sludges (SINISCALCHI et al., 2017).

Diversity was also calculated using the Shannon index $\left(\mathrm{H}^{\prime}\right)$. The $\mathrm{H}^{\prime}$ index showed practically the same diversity for both samples $\left(\mathrm{H}^{\prime}=2.4\right.$ for the inoculum and 2.6 for 35 days of testing), suggesting that the incubation time was short to reveal a difference in diversity and possible community selection, however sufficient to perform the anaerobic methane oxidation test and, consequently, methanotrophic activity 
calculation of the UASB reactor sludge.

\section{CONCLUSIONS}

The most appropriate conditions to determine methanotrophic activity were established, and methanotrophic activity from a UASB sludge was determined through four repetitions. Methanotrophs bacteria were identified by DGGE in the batch flasks and show the coexistence of aerobic bacteria in anoxic environments. A large part of methane consumption occurs from biological oxidation by methanotrophic organisms, and therefore the contribution and importance of these microorganisms within these systems are highlighted.

ACKNOWLEDGEMENTS: Thanks to the Coordination for the Improvement of Higher Education Personnel (CAPES) and the Brazilian National Council for Scientific and Technological Development (CNPq), for the resources provided to support the maintenance and development of this study.

\section{REFERENCES}

APHA. American Public Health Association. Standard Methods for the Examination of Water and Wastewater. 21 ed. APHA, 2005.

BHATTARAI, S.; CASSARINI. C.; RENE, E. R.; ZHANG, Y.; ESPOSITO, G.; LENS, P. N. L.. Enrichment of sulfate reducing anaerobic methane oxidizing community dominated by ANME-1 from Ginsburg Mud Volcano (Gulf of Cadiz) sediment in a biotrickling filter. Bioresour. Technol., v.259, p.433-441,2018.

BRANDT, E. M. F.; SANTOS, J. M. S.; SOUZA, C. L.; POSSETI, G. R. C.; RIBEIRO, T. R.; JÚNIOR, A. N. C.; CHERNICHARO, C. A. L.. Contribution for improving the design, construction and operation of UASB reactors treating sewage - Part 4: Control of corrosion and gaseous emissions. Revista DAE, v.66, n.214, p.56-72, 2018.

BRENNER, D. J.; KRIEG, N. R.; STALEY, J. T.. Bergey's manual of systematic bacteriology. The Proteobacteria - Part C: The Alpha-, Beta-, Delta- and Epsilonproteobacteria. 2 ed. Springer, 2005.

CAKIR, F. Y.; STENSTROM, M.. Greenhouse Gas Production: A comparison between aerobic and anaerobic Wastewater Treatment Technology. Water Res., v.39, p.4197-203, 2005.

CAMPELLO, L. D.; BARROS, R. M.; TIAGO, F. G. L.; SANTOS, I. F. S.. Analysis of the economic viability of the use of biogas produced in wastewater treatment plants to generate electrical energy. Environ. Dev. Sustain., v.23, n.12, 2020.

CHERNICHARO, C. A. L.; VAN LIER, J. B.; NOYOLA, A.; BRESSANI, R. T.. Anaerobic sewage treatment: state of the art, constraints and challenges. Rev. Environ. Sci. Biotechnol., v.14, n.4, p.649-679, 2015.

CHERNICHARO, C. A.. Reatores anaeróbios. Princípios do tratamento biológico de águas residuárias. 2 ed. Belo Horizonte: UFMG, 2017.
CONRAD, R.. The global methane cycle: recent advances in understanding the microbial processes involved. Environ. Microbiol., v.1, p.285-292, 2009.

CUBA, R. M. F.; DUARTE, I. C.; SAAVEDRA, N. K.; VARESCHE, M. B. A.; FORESTI, E.. Denitrification coupled with methane anoxic oxidation and microbial community involved identification. Braz. Arch. Biol. Techno., v.54, n.1, p.173-182, 2011.

DAS, S.; PETTERSSON, B. M. F.; BEHRA, P. R. K.; RAMESH, M.; DASGUPTA, S.; BHATTACHARYA, A.; KIRSEBOM, L. A.. Characterization of three mycobacterium spp. with potential use in bioremediation by genome sequencing and comparative genomics. Genome Biol. Evol., v.7, n.7, p.18711886, 2015.

EGLI, K.; LANGER, C.; SIEGRIST, H.-R.; ZEHNDER, A. J. B.; WAGNER, M.; VAN DER MEER, J. R.. Community analysis of ammonia and nitrite oxidizers during start-up of nitritation reactors. App. Environ. Microbiol. 2003; 69: 3213-3222.

ETTO, R. M.; CRUZ, L. M.; JESUS, E. C.; GALVÃO, C. W.; GALVÃO, F.; SOUZA, E. M.; PEDROSA, F. O.; STEFFENS, M. B. R.. Prokaryotic communities of acidic peatlands from the southern Brazilian Atlantic Forest. Braz. J. Microbiol., v.43, p.661-674, 2012.

ETTWIG, K. F.; VAN ALEN, T.; VAN DE PAS-SCHOONEN, K. T.; JETTEN, M. S.; STROUS, M.. Enrichment and molecular detection of denitrifying methanotrophic bacteria of the NC10 phylum. App. Environ. Microbiol., v.75, n.11, p.365662, 2009.

FINN, D. R.; ZIV-EL, M.; VAN HAREN, J.; PARK, J. G.; DEL AGUILA-PASQUEL, J.; URQUIZA-MUÑOZ, J. D.; CADILLOQUIROZ, H.. Methanogens and methanotrophs show nutrient-dependent community assemblage patterns across tropical peatlands of the pastaza-marañón basin, peruvian 
amazonia. Front. Microbiol., v.11, n.746, 2020.

GANESAN, A.; CHAUSSONNERIE, S.; TARRADE, A.; DAUGA, C.; BOUCHEZ, T.; PELLETIER, E.; LE PASLIER, D.; SGHIR, A.. Cloacibacillus evryensis gen. nov., sp. nov., a novel asaccharolytic, mesophilic, amino-acid-degrading bacterium within the phylum 'Synergistetes', isolated from an anaerobic sludge digester. Int. J. Syst. Evol. Micr., v.58, n.9, p.2003-2012, 2008.

GÜR, T. M.. Comprehensive review of methane conversion in solid oxide fuel cells: Prospects for efficient electricity generation from natural gas. Prog. Energ. Combust., v.54, p.1-64, 2016.

HO, A.; ROY, K.; THAS, O.; NEVE, J.; HOEFMAN, S.; VANDAMME, P.; HEYLEN, K.; BOON, N.. The more, the merrier: heterotroph richness stimulates methanotrophic activity. ISME J., v.8, n.9, p.1945-1948, 2014.

HO, A.; VLAEMINCK, S. E.; ETTWIG, K. F.; SCHNEIDER, B.; FRENZEL, P.; BOON, N.. Revisiting methanotrophic communities in sewage treatment plants. App. Environ. Microbiol., v.79, n.8, p.2841-2846, 2013.

KALYUZHNAYA, M. G.; PURI, A. W.; LIDSTROM, M E.. Metabolic engineering in methanotrophic bacteria. Metab. Eng., v.29, p.142-152, 2015.

KAMPMAN, C.; PIAI, L.; TEMMINK, H.; HENDRICKX, T. L.; ZEEMAN, G.; BUISMAN, C. J.. Effect of low concentrations of dissolved oxygen on the activity of denitrifying methanotrophic bacteria. Water Sci. Technol., v.77, n.11, p.2589-2597, 2018.

KNIEF, C.; LIPSKI, A.; DUNFIELD, P. F.. Diversity and activity of methanotrophic bacteria in different upland soils. App. Environ. Microbiol., v.69, n.11, p.6703-6714, 2003.

LOBATO, L.; CHERNICHARO, C.; SOUZA, C.. Estimates of methane loss and energy recovery potential in anaerobic reactors treating domestic wastewater. Water Sci. Technol., v.66, n.12, p.2745-2753, 2012.

LUESKEN, F. A.; VAN ALEN, T. A.; VAN DER BIEZEN, E.; FRIJTERS, C.; TOONEN, G.; KAMPMAN, C.; HENDRICKX, T. L. G.; ZEEMAN, G.; TEMMINK, H.; STROUS, M.; OP DEN CAMP, H. J. M.; JETTEN, M. S. M.. Diversity and enrichment of nitrite-dependent anaerobic methane oxidizing bacteria from wastewater sludge. App. Microbiol. Biotechnol., v.92, n. 4, p.845, 2011.

MARTINEAU, C.; WHYTE, L. G.; GREER, C. W.. Stable isotope probing analysis of the diversity and activity of methanotrophic bacteria in soils from the Canadian high Arctic. App. Environ. Microbiol., v.76, n.17, p.5773-84, 2010.

MATSUURA, N.; HATAMOTO, M.; YAMAGUCHI, T.; OHASHI,
A.. Methanotrophic community composition based on pmoA genes in dissolved methane recovery and biological oxidation closed downflow hanging sponge reactors. Biochem. Engin. J., v.124, p.138-144, 2017.

MEULEPAS, R. J. W.; JAGERSMA, C. G.; ZHANG. Y.; PETRILLO, M.; CAI, H.; BUISMAN, C. J. N.; STAMS, A. J. M.; LENS, P. N. L.. Trace methane oxidation and the methane dependency of sulfate reduction in anaerobic granular sludge. FEMS Microbiol. Ecol., v.72, n.2, p.261-271, 2010.

ROSA, A. P.; CONESA, J. A.; FULLANA, A.; MELO, G. C. B.; BORGES, J. M.; CHERNICHARO, C. A. L.. Energy potential and alternative usages of biogas and sludge from UASB reactors: case study of the Laboreaux wastewater treatment plant. Water Sci. Technol., v.73, n.7, p.1680-1690, 2015.

SANTOS, I.; BARROS, R.; FILHO, G.. Electricity generation from biogas of anaerobic wastewater treatment Plants in Brazil: An assessment of feasibility and potential. Journal of Cleaner Production., v.12, p.504-514, 2016.

SINGLETON, D. R.; GUZMÁN-RAMIREZ, L.; AITKEN, M. D. Characterization of a polycyclic aromatic hydrocarbon degradation gene cluster in a phenanthrene-degrading em Acidovorax strain. App. Environ. Microbiol., v.75, n.9, p.2613-2620, 2009.

SINISCALCHI, L.; LEITE, L.; OLIVEIRA, G.; CHERNICHARO, C.; ARAUJO, J.. Illumina sequencing-based analysis of a microbial community enriched under anaerobic methane oxidation condition coupled to denitrification revealed coexistence of aerobic and anaerobic methanotrophs. Environ Sci. Pollut. R., v.24, n.20, p.16751-16764, 2017.

SNIS. Sistema Nacional de Informações sobre Saneamento. Informações para planejar o esgotamento sanitário. Brasília: Ministério do Desenvolvimento Regional, 2020.

STOTHARD, P.. The Sequence Manipulation Suite: JavaScript programs for analyzing and formatting protein and DNA sequences. Biotechniques., v.28, p.1102-1104, 2000

TESSARO, S.. Estudo da comunidade de bactérias metanotróficas em uma cronossequência de solos da Amazônia. Dissertação (Mestrado) - Universidade de São Paulo, São Paulo, 2012.

VON SPERLING, M.. Introdução à qualidade das águas e ao tratamento de esgotos. Princípios do tratamento biológico de águas residuárias. 4 ed. Belo Horizonte: UFMG, 2014.

ZEKKER, I.; RIKMANN, E.; TENNO, T.; KROON, K.; SEIMAN, A.; LOORITS, L.; FRITZE, H.; TUOMIVIRTA, T.; VABAMÄE, P.; RAUDKIVI, M.; MANDEL, A.; TENNO, T.. Start-up of lowtemperature anammox in UASB from mesophilic yeast factory anaerobic tank inoculum. Environ Technol., v.36, n.2, p.214-225, 2015

A CBPC - Companhia Brasileira de Produção Científica (CNPJ: 11.221.422/0001-03) detém os direitos materiais desta publicação. Os direitos referem-se à publicação do trabalho em qualquer parte do mundo, incluindo os direitos às renovaç̃os, expansões e disseminações da contribuição, bem como outros direitos subsidiários. Todos os trabalhos publicados eletronicamente poderão (a) preservam os direitos autorais, mas não têm permissão para a publicação da contribuição em outro meio, impresso ou digital, em português ou em tradução. 